\title{
Double alignments of ammonoid aptychi from the Lower Cretaceous of Southeast France: Result of a post-mortem transport or bromalites?
}

Stéphane Reboulet and Anthony Rard

Acta Palaeontologica Polonica 53 (2), 2008: 261-274 doi:http://dx.doi.org/10.4202/app.2008.0207

A new preservation of aptychi is described from the Valanginian limestone-marl alternations of the Vergol section (Drôme), located in the Vocontian Basin (SE France). Aptychi are arranged into two parallel rows which are generally $50 \mathrm{~mm}$ in length and separated by $4 \mathrm{~mm}$. The alignments are very often made by entire aptychi (around $10 \mathrm{~mm}$ in length), oriented following their harmonic margin. Aptychi show the outside of valve to the viewer: they are convex-up. This fossilization of aptychi is successively interpreted as the result of post-mortem transport by bottom currents (taphonomic-resedimentation process) or the residues (bromalites: fossilized regurgitation, gastric and intestinal contents, excrement) from the digestive tract of an ammonoid-eater (biological processes). Both the parallel rows of aptychi are more likely interpreted as a coprolite (fossil faeces) and they could be considered as both halves (hemi-cylindrical in shape) of the same cylindrical coprolite which would have been separated in two parts (following the long axis) just after the animal defecated. Considering this hypothesis, a discussion is proposed on the hypothetical ammonoid-eater responsible for them.

Key words: Ammonoidea, taphonomy, aptychus, coprolite, predation, Valanginian, Cretaceous, France

Stéphane Reboulet [stephane.reboulet@univ-lyon1.fr], Université de Lyon, (UCBL1, La Doua), UFR des Sciences de la Terre, CNRS-UMR 5125 PEPS, Bâtiment Géode, 2 Rue Raphaël Dubois, 69622

Villeurbanne cedex, France; Anthony Rard [anthony.rard@cc-thouarsais.fr], Centre d'interprétation géologique du Thouarsais, Réserve Naturelle Géologique du Toarcien, Les Ecuries du Château, 79100 Thouars, France.

This is an open-access article distributed under the terms of the Creative Commons Attribution License (for details please see creativecommons.org), which permits unrestricted use, distribution, and reproduction in any medium, provided the original author and source are credited. 
Fof Full text $(1,113.3 \mathrm{kB})$ 